Jarostaw Kita

Wojciech Marciniak

(Uniwersytet Łódzki, Wydział Filozoficzno-Historyczny)

\title{
LOSY POLAKÓW NA WSCHODZIE OD EPOKI ZABORÓW, PRZEZ TRAGICZNY WIEK DWUDZIESTY DO TRUDNEJ WSPÓLCZESNOŚCI
}

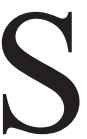

ybir, zesłanie, tułaczka, katorga - to doświadczenia towarzyszące kolejnym pokoleniom Polaków, których dotknęła opresyjna polityka wschodniego sąsiada naszego kraju - Rosji (ZSRR). Niezależnie od historycznych form władzy, która sprawowała rządy nad Newą czy na Kremlu, polskie losy na Wschodzie przywołują na myśl najczęściej te martyrologiczne karty historii ojczystej. Faktycznie - represje, jakich doznało wielu Polaków ze strony państwa rosyjskiego (i radzieckiego), były tak dotkliwe, że trudno o inne skojarzenia. Jednak nie sposób zapominać także o innych aspektach dziejów naszych rodaków na tych obszarach. Wśród nich należy wyszczególnić działalność zesłańców - wybitnych polskich uczonych doby rozbiorowej, którzy wnieśli ogromny wkład w poznanie i opisanie najodleglejszych rejonów Syberii. Życiorysy i spuścizny m.in. Aleksandra Czekanowskiego, Jana Czerskiego, Benedykta Dybowskiego czy Wacława Sieroszewskiego to przecież spora i bardzo ważna część polskiej historii ${ }^{1}$.

Pierwsze pokolenie polskich zesłańców na Syberii znalazło się tam jeszcze w XVIII w. po przegranej konfederacji barskiej (pamiętając jednocześnie o jeńcach polskich z wojen z Rosją w XVII w.). Następne, znaczne pod względem liczebnym zsyłki, stawały się konsekwencją kolejnych przegrywanych dziewiętnastowiecznych powstań narodowych, a w ostatnich dekadach epoki zaborowej były wynikiem działalności konspiracyjnej i rewolucyjnej podejmowanej przez

${ }^{1}$ Spośród wielu prac o ogólnych charakterze można wskazać chociażby następujące: W. Śliwowska, Zestańcy polscy w Imperium Rosyjskim w pierwszej połowie XIX wieku, Warszawa 1998; A. Brus, E. Kaczyńska, W. Śliwowska, Zestanie i katorga na Syberii w dziejach Polaków 18151914, Warszawa 1992; Polacy w nauce, gospodarce i administracji na Syberii w XIX i na poczatku XX wieku, pod red. naukową A. Kuczyńskiego, Wrocław 2007; Syberia w historii i kulturze narodu polskiego, pod red. A. Kuczyńskiego, Wrocław 1998; A. Kuczyński, Syberia. 400 lat polskiej diaspory. Zesłania, martyrologia i sukces cywilizacyjny Polaków. Rys historyczny, antologia, [Krzeszowice] 2007; E. Kaczyńska, Syberia największe więzienie świata, Warszawa 1991; F. Nowiński, Polacy na Syberii Wschodniej. Zestańcy polityczni w okresie międzypowstaniowym, Gdańsk 1995; H. Skok, Polacy nad Bajkatem 1863-1883, Warszawa 1974. 
późniejsze pokolenia Polaków. Najwięcej naszych rodaków trafiło na Syberię Wschodnią i Zachodnią w wyniku klęski powstania styczniowego. Stąd też trudno dziwić się, iż w historiografii polskich zesłań w XIX w. zdecydowanie dominują opracowania poświęcone tej właśnie populacji polskich Sybiraków. Katalog polskiej historiografii obejmującej dziewiętnastowieczną tematykę losów polskich na Wschodzie jest bardzo obszerny. Nie sposób wymienić nawet wszystkich najważniejszych monografii, aby nie urazić kogokolwiek. Warto odnotować, że dla polskojęzycznego czytelnika dostępnych jest coraz więcej prac rosyjskich autorów wykorzystujących materiały źródłowe pochodzące z rosyjskich, a szczególnie syberyjskich archiwów ${ }^{2}$. Najważniejsze pozycje znajdują się w przypisach i bibliografii artykułów zamieszczonych w poszczególnych tekstach w niniejszych tomach.

Problematykę losów Polaków na zesłaniu w XIX w. można rozważać na wielu płaszczyznach badawczych, odwołując się przy tym do szczególnego zespołu indywidualnych i zbiorowych doświadczeń Polaków, które znajdują odbicie również w bogatej literaturze pamiętnikarskiej z tego zakresu. Dziesiątki obszernych pamiętników i drobniejszych wspomnień zostało już opublikowanych, ale jeszcze inne spoczywają w archiwach w co najmniej w kilku krajach, a najpewniej i w rodzinnych spuściznach po przodkach.

Wiele z nich powinno niebawem zostać udostępnionych badaczom i szerszemu kręgowi odbiorców, dzięki inicjatywom podjętym przez kieleckich historyków. Zainicjowane przez nich projekty badawcze o międzynarodowym składzie uczonych [„,Pamiętniki i listy polskich autorów z Ziem Zabranych (Litwa, Białoruś, Ukraina) w latach 1795-1918” - umowa nr 0083/NPRH2/H11/81/2012 oraz „Polscy zesłańcy na Syberii Zachodniej w drugiej połowie XVIII - XIX wiek w oczach Rosjan i ludności syberyjskiej" - umowa nr 0098/NPRH3/H12/82/2014] powinny z pewnością przynieść znakomite owoce. Niektóre z tych memuarów i kolekcji listów ze Wschodu zostało już zinwentaryzowanych, bądź wydanych drukiem³

Dwudziestowieczne dzieje to już inny rozdział - masowe represje wobec Polaków-obywateli ZSRR w latach trzydziestych, zsyłki i deportacje mieszkańców II Rzeczypospolitej w okresie II wojny światowej, czy uwięzienia w łagrach „archipelagu GUŁAG” w powojennym okresie stalinowskim, to epoka brutalnej rozprawy totalitarnego reżimu z Polakami. Carska zsyłka, czy nawet katorga, to zupełnie coś innego, niż stalinowskie łagry, więzienia i wygnanie. Łączy je tylko kierunek geograficzny - Wschód. Ta problematyka od lat cieszy się niesłabnącym

2 Tytułem przykładu monografia wieloautorska: Польские ссыльные в Сибирии во второй половине XVIII-начале XX века в восприятии российской администрации, переселенцев и коренных народов Сибирии, ред. С. А. Мулина и др., Омск 2015.

3 Pamiętniki i listy polskich autorów z Ziem Zabranych (Litwa. Białoruś, Ukraina) w latach 1795-1918. Materiaty do katalogu, t. II, Listy rękopiśmienne i drukowane, oprac. i red. naukowa M. Domańska-Nogajczyk, T. Wójcik, W. Caban, L. Michalska-Bracha, Kielce 2017, ss. 516. 
zainteresowaniem nie tylko historyków, ale także antropologów, filologów, kulturoznawców czy socjologów. Także niezawodowi pasjonaci przeszłości podejmują bardzo udane próby odtworzenia losów polskich na Wschodzie ${ }^{4}$.

Warto odnotować, że prace badawcze w interesującej nas tematyce to domena już nie tylko uczelni, ale także innych placówek badawczo-edukacyjnych. Dla przykładu warto podkreślić działalność naukową, popularyzatorską i wydawniczą instytucji, które działają od stosunkowo krótkiego czasu - Muzeum Pamięci Sybiru w Białymstoku (od 2 stycznia 2017 r. samodzielnej instytucji muzealnej, a wcześniej Oddział Muzeum Wojska w Białymstoku) $)^{5}$ czy Centrum Polsko-Rosyjskiego Dialogu i Porozumienia (powołane w 2011 r.) ${ }^{6}$ oraz Centrum Dokumentacji Zsyłek, Wypędzeń i Przesiedleń w Krakowie (istnieje od 2010 r.) 7. Bardzo ważne i potrzebne inicjatywy od wielu lat podejmuje także Fundacja Ośrodka KARTA w Warszawie. Dokonania i osiągnięcia tej instytucji na polu badawczym, wydawniczym, a także archiwizacji i popularyzacji wiedzy o Polakach na Wschodzie są nie do przecenienia. Warto, by były także odpowiednio doceniane przez władze państwowe.

W ostatnich latach wątki podejmowane przez krajowych badaczy związane z tytułową tematyką są bardzo zróżnicowane. Wśród wyróżniających się pozycji, jakie w ostatnim czasie ukazały się na rynku księgarskim, należy wymienić opracowanie Albina Głowackiego z Uniwersytetu Łódzkiego o działalności Komitetu do Spraw Dzieci Polskich w ZSRR ${ }^{8}$. Autor książki został uhonorowany Nagrodą „Przeglądu Wschodniego" 2017. Warto wyszczególnić także zainteresowanie polskich historyków tematyką kobiet-zesłańców ${ }^{9}$, dziejami kościoła na Wschodzie ${ }^{10}$

${ }^{4}$ Dobrym przykładem jest tutaj publikacja: K. Ćwiertniewski, $W$ kręgu rodowym „Cioci Antosi” - Michaliny z Lubiczanowskich Wieszeniewskiej, [Łódź 2012]. Autor, wykorzystując archiwalia i rodzinne materiały, przedstawił bardzo interesujące losy swoich przodków na tle przełomowych wydarzeń z dziejów Polski w XIX i XX w.

${ }^{5}$ Sybir. Doświadczenia - Pamięć, tom pokonferencyjny pod red. A. Głowackiego, Białystok 2015; Sybir. Wiara, nadzieja, przetrwanie, [red. nauk. W. Śleszyński], Białystok 2017.

${ }^{6}$ Sowieci a polskie podziemie 1943-1946. Wybrane aspekty stalinowskiej polityki represji, pod red. Ł. Adamskiego, G. Hryciuka, G. Motyki, Warszawa 2017; M. Wyrwa, Nieodnalezione ofiary Katynia? Lista osób zaginionych na obszarze pólnocno-wschodnich województw II RP od 17 września 1939 do czerwca 1940, Warszawa 2015.

${ }^{7}$ Realizując swoje zadania statutowe, Centrum zbiera, archiwizuje i upowszechnia informacje o Polakach represjonowanych przez reżim stalinowski. Pracownicy Centrum docierają do rozsianych po całym świecie żyjących świadków historii i spisują ich relacje, ocalając tym samym od fizycznego unicestwienia przeżycia ostatnich ludzi, którzy są w stanie opowiedzieć swoje przeżycia sprzed dziesiątek lat.

${ }^{8}$ A. Głowacki, Na pomoc zesłańczej edukacji. Działalność wydawnicza Komitetu do Spraw Dzieci Polskich w ZSRR (1943-1946), Łódź 2017.

${ }^{9}$ A. Herbich, Dziewczyny z Syberii. Prawdziwe historie, Kraków 2015.

${ }^{10}$ B. Michalewski, Polscy zestańcy w obronie wiary. Kościót katolicki w sowieckim Kazachstanie w latach 1936-1990, Krzeszowice 2016. 
czy kwestiami repatriacji ${ }^{11}$. Związane $\mathrm{z}$ tą ostatnią problematyką są także wydane ostatnio tomy zawierające źródła archiwalne ${ }^{12}$. Na uwagę zasługują również wydawnictwa zbiorowe, nawiązujące do ważnych rocznic historycznych - oczywiście powiązanych z problematyką polskich losów na Wschodzie ${ }^{13}$. Tematyka zesłańcza, ale także związana z dziejami Polaków na Kresach Wschodnich, pojawia się w publikowanej nie tylko w ostatnim czasie memuarystyce i korespondencji ${ }^{14}$.

Lista zagadnień wynikających z tytułowej problematyki jest, jak widać, bardzo obszerna. Co roku w Polsce organizowanych jest co najmniej kilka konferencji, podczas których zgłębiający ją historycy (ale nie tylko) mają okazję do zaprezentowania wyników swoich badań. Do grona organizatorów tego typu przedsięwzięć postanowił dołączyć także Instytut Historii Uniwersytetu Lódzkiego. W dniach 5-6 grudnia 2016 r. w jego murach odbyła się sesja naukowa poświęcona trudnym, często tragicznym, ale także bardzo interesującym losom Polaków na Wschodzie. Jej ramy chronologiczne były szerokie - od czasów zaborów do współczesności. Pretekstem do tego naukowego spotkania polskich badaczy było stupięćdziesięciolecie powstania zabajkalskiego (1866 r.) oraz 70 . rocznica zakończenia pierwszej, masowej repatriacji polskich zesłańców z głębi Związku Radzieckiego (1946 r.). W konferencji uczestniczyło 27 przedstawicieli z 11 krajowych ośrodków naukowo-badawczych. Tematyka wystąpień była zróżnicowana - pojawiły się w nich m.in. wątki dotyczące podróży na zesłanie w głąb Imperium Rosyjskiego (ZSRR), mitów związanych z pobytem Polaków na wygnaniu, życia codziennego na zsyłce w Rosji (ZSRR) czy represji stalinowskich. Nie zabrakło także referatów biograficznych oraz przybliżających działalność organizacji skupiających Polaków (np. Związku Patriotów Polskich), czy dotyczących kwestii prawnych, a także problematyki życia Polonii na Wschodzie w czasach współczesnych. W intencji organizatorów spotkanie w Łodzi było próbą zintegrowania środowiska historyków (i nie tylko), zajmujących się tematyką polskich losów w Cesarstwie Rosyjskim i w ZSRR oraz w państwach powstałych na gruzach imperium radzieckiego, a także zaprezentowanie i podsumowanie aktualnych wyników badań. To zadanie zostało zrealizowane, a w zamierzeniach Instytutu Historii UŁ pozostaje przygotowanie kolejnych inicjatyw naukowych dotyczących tej problematyki.

${ }^{11}$ K. Kość-Ryżko, Wykorzenieni. Dylematy samookreślenia polskich repatriantów z Kazachstanu. Studium etnopsychologiczne, Warszawa 2014.

${ }^{12}$ „Druga repatriacja” ludności polskiej z ZSRR na Warmii i Mazurach. Wybór dokumentów z zasobu Archiwum Państwowego w Olsztynie z lat 1955-1962, wybór i wstęp M. Korejwo, Olsztyn 2016; Polska Delegacja w Polsko-Radzieckiej Komisji Mieszanej Do Spraw Ewakuacji. Wybór dokumentów (1945-1947), wstęp i oprac. W. Marciniak, [Łódź 2016].

${ }^{13}$ Między Wilnem a Olsztynem. W siedemdziesiąta rocznicę przybycia Polaków z Wileńszczyzny na Warmię i Mazury, pod red. P. Bojarskiego i A. Szmyta, Olsztyn 2016.

${ }_{14}$ M. Aleksandrowicz, Wspomnienia ze stuletnia historia $w$ tle, wstęp i oprac. W. Gieszczyński, Olsztyn 2017; Syberia w listach i dokumentach zesłańców (1928-1946), oprac. Z. Fedus, Wrocław 2015. 
Do rąk P.T. czytelników oddajemy dwa tomy (17 i 18) „Studiów z Historii Społeczno-Gospodarczej XIX i XX wieku", które zawierają znaczną część drukowanych wersji referatów wygłoszonych podczas sesji. Podzieliliśmy je pod względem chronologicznym na dwie części. O ich zakresie tematycznym i chronologicznym świadczą nadane im tytuły: tom 17 - Losy Polaków na Wschodzie. Epoka zaborów i poczatek XX wieku i tom 18 - Losy Polaków na Wschodzie. Wiek $X X i$ wspótczesność. Oba tomy zostały wydane pod redakcją naukową organizatorów wspomnianej konferencji - Jarosława Kity i Wojciecha Marciniaka.

Tom 17 zawiera 10 artykułów dotyczących Polaków przebywających na Wschodzie w latach zaborów. Zdecydowanie dominują teksty dotyczące losów polskich zesłańców syberyjskich, którzy znaleźli się tam, nie ze swej woli, w wyniku represji po klęsce powstania styczniowego. Tom otwiera artykuł opracowany przez WieSŁaWa CABANa i Lidį̨ MichalSKĄ-BraChĘ (Uniwersytet Jana Kochanowskiego w Kielcach), znakomitych badaczy tej tematyki. Tekst napisany na wysokim poziomie erudycyjnym i warsztatowym ujmuje syntetycznie problematykę zesłańców syberyjskich w latach 60.-90. XIX stulecia. Opracowanie oparte zostało na szerokiej podstawie źródłowej. W pierwszej jego części Autorzy rozprawiają się z historiograficznym mitem (mitami) Sybiru, wykazując najwyższy poziom znajomości problematyki. Stawiają przy tym interesujące pytania badawcze. Z kolei w drugiej części, podejmują również krytyczną analizę historiografii radzieckiej, rosyjskiej i polskiej dotyczącej tematyki zesłań na Syberię $\mathrm{w}$ interesującym ich okresie.

Kolejny tekst jest autorstwa Jolanty SiKorsKiej-Kuleszy (Uniwersytet Warszawski). Ten interesujący artykuł oparty został na fragmencie pozostającego jeszcze w rękopisie pamiętnika Władysława Zahorskiego i bogatej literaturze przedmiotu. Autorka z dużym wyczuciem i ostrożnością formułuje wnioski, które w przypadku tego typu źródła (zwłaszcza materiału wspomnieniowego spisywanego po latach) takiej przezorności wymaga. Artykuł dotyka problematyki zesłańców w Ufie obserwowanej niejako z pozycji dziecka (W. Zahorski był nim przebywając w Ufie) z rodziny inteligenckiej z ziem zabranych, której sytuacja, pozycja społeczna i status materialny były zdecydowanie lepsze niż tych Polaków, którzy w realiach postyczniowych przebywali tam na przymusowej zsyłce.

Z kolei JAROSŁAW KITA (Uniwersytet Łódzki) podjął się zadania zilustrowania problematyki zesłań syberyjskich ludności wywodzącej się z regionu łódzkiego. Wzbogacił tym samym wiedzę na temat losów zesłańców postyczniowych odnosząc się do konkretnego regionu ich pochodzenia. Autor w pierwszej części dokonał analizy demograficznej grupy, która została skazana na roboty lub osiedlenie się na Syberii. Zaś w drugiej części mamy do czynienia z przedstawieniem samej peregrynacji i syberyjskich losów na podstawie zachowanego materiału pamiętnikarskiego. 
EmIL NorŃski (Muzeum Józefa Piłsudskiego w Sulejówku) zamieścił interesujący tekst dotyczący losów kontrowersyjnej w oczach współczesnych aktorki Heleny Kirkorowej. Autor skupia swoją uwagę na roli, jaką odegrała ona w powstaniu styczniowym. Jej losy na zesłaniu syberyjskim, z uwagi na brak odpowiednich źródeł, są potraktowane nieco bardziej ogólnie na tle życia osób, z którymi miała tam kontakt. Niełatwe zadanie odtworzenia biografii aktorki, która nie pozostawiła po sobie egodokumentów, wymagało wytrwałych poszukiwań w rozproszonym materiale źródłowym oraz w dziełach publikowanych i temu zadaniu Autor sprostał.

Kolejny tekst, zamieszczony w języku rosyjskim najbliższym jego Autorowi, czyli ANTONOWi LuTYŃSKIEMU (Wołogda), powinien być niezmiernie przydatnym dla badaczy problematyki dominującej w tym tomie „Studiów”. Ten wartościowy artykuł, obok przeglądu historiografii rosyjskiej, poruszającej problematykę obecności Polaków na Syberii w XIX stuleciu, zawiera szczegółową charakterystykę stanu badań nad dziewiętnastowiecznymi zesłańcami w guberni wołogodzkiej. Autor nie tylko szczegółowo analizuje naukowe publikacje dotyczące Polaków w guberni wołogodzkiej, ale również wskazuje obszary zasługujące na zainteresowanie badaczy w przyszłości. Ponadto artykuł zawiera cenne wskazówki dotyczące zbiorów dokumentów znajdujących się w zasobach archiwów rosyjskich (i nie tylko), które stanowią podstawę do badań różnych aspektów obecności Polaków na Syberii.

Problemem powstania zabajkalskiego w $1866 \mathrm{r}$. i pamięcią o nim zajął się WoJCIECH ŚlesZyŃSKi (Uniwersytet w Białymstoku). Artykuł składa się z trzech części tematycznych. Pierwsza poświęcona jest problematyce badawczej pamięci (Autor daje tutaj interesującą refleksję na temat struktur i roli kultury pamięci). Druga część skupia się wokół powstania zabajkalskiego z 1866 r. i jego miejsca w pamięci Polaków oraz mieszkańców Syberii. W końcu trzecia część, dotyczy projektu białostockiego Muzeum Pamięci Sybiru, które za cel stawia sobie popularyzowanie wiedzy o losach Polaków na Syberii, w tym również o powstaniu zabajkalskim.

Opisom i wrażeniom z podróży przez Syberię na front wojny rosyjsko-japońskiej poświęcił tekst JACEK LeGIEĆ (Uniwersytet Jana Kochanowskiego w Kielcach). Artykuł podejmuje problematykę, która w dotychczasowych badaniach nie doczekała się swojego poważniejszego opracowania - udziału Polaków w wojnie rosyjsko-japońskiej. Na uwagę zasługuje zarówno wybór interesującej podstawy źródłowej, jaką stanowią listy szeregowych żołnierzy pochodzących głównie z polskiej wsi, jak i trafne spostrzeżenia i wnioski, świadczące o znakomitej znajomości tematu przez Autora. Zarówno zawarte w tekście informacje, jak i konkluzje o charakterze ogólnym poszerzają stan naszej historiografii, dając obraz podróży Polaków - szeregowych żołnierzy armii rosyjskiej do Mandżurii. 
Kolejne opracowanie autorstwa StanisŁawa Wiecha (Uniwersytet Jana Kochanowskiego w Kielcach) podejmuje jeszcze inny wątek podróży na syberyjskie zesłanie. Mało znane w historiografii polskiej wspomnienia Florian Bohdanowicza (Bogdanowicza) z pobytu na Syberii są znakomitym źródłem do analizy warunków bytowych polskich zesłańców przełomu lat 70. i 80. XIX w., panujących w tym środowisku relacji społecznych, stosunku do polskich zesłańców miejscowej ludności oraz urzędników carskiej administracji. Zamieszczony we wspomnieniach szczegółowy opis podróży na zesłanie stanowi z kolei ciekawy i wydaje się reprezentatywny dla przełomu lat 70. i 80. XIX w. przykład długiej, uciążliwej i niezwykle bogatej we wrażenia i doznania osobiste peregrynacji polskich zesłańców.

Dotychczas zasygnalizowane artykuły zostały napisane przez doświadczonych badaczy, mających najczęściej uznany i cytowany w licznych opracowaniach dorobek naukowy. Jednak badania nad problemami związanymi z Polakami na Wschodzie, głównie przez pryzmat losów zesłańców postyczniowych, podejmuje też najmłodsze pokolenie polskich historyków. Przykładem ich pierwszych ustaleń badawczych są dwa ostatnie artykuły zamieszczone w tym tomie czasopisma.

Losami polskich kobiet udających się na syberyjskie zesłanie zajął się WoJCIECH CEDRo (Uniwersytet Jana Kochanowskiego w Kielcach). W jego artykule dotyczącym podróży Polek na zesłanie na daleką Syberię mamy do czynienia z analizą dwóch publikowanych relacji pamiętnikarskich - Jadwigi Prebendowskiej i Marii Obuchowskiej-Morzyckiej. Pierwsza z kobiet została skazana na zesłanie ze względu na prowadzoną działalność niepodległościową, natomiast druga udała się tam z własnej woli, towarzysząc mężowi-zesłańcowi. Na podstawie ich memuarów Autor dochodzi do wniosków ogólnych odnośnie warunków przejazdu, zagrożeń czyhających na kobiety, stosunków zesłańców z Rosjanami i rodakami, diety, umiejętności przetrwania. Przedstawiony obraz podróży wzbogaca przede wszystkim wiedzę na temat życia codziennego zesłańców - mężczyzn i kobiet.

Natomiast $\mathrm{w}$ ostatnim $\mathrm{z}$ artykułów innych młody kielecki badacz ŁUKASZ WoŁcZYK (Uniwersytet Jana Kochanowskiego w Kielcach) stawia sobie za cel przedstawienie drogi na Syberię w świetle publikowanych wspomnień dwóch braci - Ludwika i Kornela Zielonków. Bracia odbywają drogę na zesłanie w innych partiach i w różnym czasie. Autor zderza więc ze sobą ich relacje, które w wielu miejscach różnią się od siebie. Kiedy Ludwik Zielonka skupia się przede wszystkim na emocjach w dużej mierze negatywnych i ironizowaniu niektórych sytuacji, to drugi z braci - Kornel - obserwuje i zdaje niekiedy wręcz poetycką relację, nie pomijając, rzecz jasna, emocji jakie odczuwał. Starał się jednak nie eksponować ich w tak wyraźny sposób jak brat. 
Tom 17 „Studiów z Historii Społeczno-Gospodarczej XIX i XX wieku” uzupełniają trzy interesujące artykuły recenzyjne, recenzje i sprawozdanie z cyklicznej konferencji. W pierwszym z artykułów recenzyjnych, JACEK PIETRZAK (Uniwersytet Łódzki), w napisanym z polotem tekście, przybliża świat wiktoriańskiej, londyńskiej salonniére poprzez pryzmat biografii Gertrude Tennant, autorstwa Davida Wallera.

Dwa kolejne, obszerne teksty powiązane są ze sobą nicią polemiki naukowej przedstawicieli dwóch pokoleń łódzkich historyków - KRZYSZTOFA P. WoŹNIAKA i KAMILA ŚmiechowsKIEGo. Bardzo interesująca i merytoryczna polemika toczy się wokół książki - postulatu badawczego, poświęconej łódzkim robotnikom drugiej połowy XIX stulecia.

Ponadto w tomie tym czytelnik znajdzie recenzję ostatniej książki Magdaleny Gawin, przygotowaną przez Mateusza KowALSKIEGO i ocenę cennej monografii Joanny Sadowskiej, pióra WIEStawa PusIA. Tom zamyka sprawozdanie ŁuKAsZA BIAŁEGo z cyklicznej, piątej już, Ogólnopolskiej Sesji Naukowej pt. Życie prywatne Polaków w XIX wieku, tym razem z podtytułem „Prywatne światy zamknięte w listach", organizowanej wspólnie przez Instytut Historii Uniwersytetu Łódzkiego oraz Instytut Historii i Stosunków Międzynarodowych Uniwersytetu Warmińsko-Mazurskiego w Olsztynie.

Z kolei tom 18 ,Studiów” zawiera część drugą artykułów dotyczących wieku dwudziestego oraz współczesności. Znalazło się w nim 11 tekstów powiązanych nadrzędnych problemem badawczym „Polacy na Wschodzie”. Tom otwiera opracowanie Anny MiLewskiej-Mıynik (Muzeum Niepodległości w Warszawie) o zesłańczych losach Marii Karasińskiej. Autorka oparła się w dużej mierze na unikatowym źródle - pamiętniku swojej bohaterki przechowywanym w zbiorach Muzeum Niepodległości w Warszawie. Wykorzystując to źródło, jak również inny materiał pamiętnikarski stworzony przez osoby, które zetknęły się na zsyłce z Marią Karasińską, odtworzyła wojenne (i częściowo także powojenne) losy swojej bohaterki - osoby wrażliwej i niezwykle utalentowanej muzycznie. A były to losy bardzo tragiczne, bowiem Karasińska wiosną 1940 r. została deportowana przez Sowietów do Kazachstanu. Do Polski powróciła w wyniku masowej repatriacji w $1946 \mathrm{r}$.

O życiu codziennym Polaków osadzonych po 1944 r. w obozach NKWD w Charkowie, Riazaniu i Borowiczach opowiada artykuł AleKsandry Arkusz (Uniwersytet Jagielloński). Autorka skreśliła bardzo interesujący, ale i miejscami wstrząsający obraz egzystencji obywateli polskich, pozbawionych wolności przez Sowietów i przetrzymywanych pod strażą. W opracowaniu znalazło się sporo szczegółowych danych (np. o normach żywieniowych), które są konieczne do pełniejszego przedstawienia okoliczności, w których przyszło przez wiele miesięcy żyć Polakom - w większości żołnierzom Armii Krajowej. 
$\mathrm{Z}$ artykułem A. Arkusz koresponduje tematycznie obszerne opracowanie autorstwa DARIUSZa WĘGRZYNA (Biuro Badań Historycznych Oddziału Instytutu Pamięci Narodowej w Katowicach). Dotyczy ono historii obozu NKWD/MWD nr 503 w Kemerowie. Autor skupił się przede wszystkim na losach więźniów pochodzących z obszarów Europy Środkowo-Wschodniej, które zostały wyzwolone spod okupacji niemieckiej przez Armię Czerwoną. Zasadnicze rozważania D. Węgrzyn poprzedził wprowadzeniem o skali i formie radzieckich represji, jakim Sowieci poddali „nieprawomyślnych” (lub o „nieprawomyślność” podejrzewanych) mieszkańców państw regionu. Autor, wykorzystując materiały archiwalne i obcojęzyczną (rosyjską) literaturę i źródła, przedstawił bardzo wiarygodny obraz funkcjonowania obozu. Poruszył wątki dotyczące m.in. administracji i życia codziennego łagru. Ciekawe i bardzo wartościowe spostrzeżenia D. Węgrzyna dotyczą także kategoryzacji osób represjonowanych.

Nad pojęciem repatriacji ze Wschodu oraz związanym z nim trybem nabywania obywatelstwa polskiego w dwudziestym i na początku dwudziestego pierwszego stulecia pochylił się z kolei WoJCIECH MarciniaK (Uniwersytet Łódzki). Artykuł ma charakter przeglądowy i znajdziemy w nim uwagi porządkujące terminologię używaną do określania ruchów migracyjnych Polaków ze Wschodu (z Rosji, ZSRR i państw, które powstały po jego rozpadzie).

Historią rodzinną zajęła się natomiast BEATA JózKów (Uniwersytet Zielonogórski). W swoim opracowaniu bardzo interesująco przedstawiła dzieje swoich przodków - mieszkańców Odelska. Wieś Odelsk (do 1934 r. miasto) obecnie leży w granicach Białorusi. Jak zaznaczyła Autorka - odelszczanie zostali ,skrzywdzeni przez historię", bowiem linia Curzona, będąca podstawą wytyczenia granicy polsko-radzieckiej po II wojnie światowej, przebiegała na wschód od jej granic. Mimo to miejscowość znalazła się po stronie radzieckiej. B. Józków, wykorzystując materiały wspomnieniowe członków swojej rodziny, bardzo starannie i z autentyczną pasją opisała historię rodu, przeplatając ją dziejami Odelska.

Koleje losu duchownych i wiernych kościoła katolickiego w Żytomierzu stały się natomiast tematem opracowania AndRZEJA KoBUSA (Uniwersytet Jana Kochanowskiego w Kielcach, Filia w Piotrkowie Trybunalskim). Tytułowy zakres chronologiczny jego rozważań dotyczy wprawdzie lat 1917-1991, ale Autor poprzedził je wprowadzeniem o historii Żytomierza począwszy od XVI w. Zasadniczą część artykułu wypełnił opis represji i zwalczania duchowieństwa katolickiego w tym mieście (i jego okolicach) w okresie radzieckim (szczególnie w latach stalinizmu).

Nieco odleglejsze od tytułowej tematyki tomu jest opracowanie KaTARZYNY ŚLIWAK (Uniwersytet Wrocławski), która przedstawiła dzieje Związku Nauczycielstwa Polskiego w Iranie w latach 1943-1945. Jego działaczami i członkami byli jednak w większości ci, którzy opuścili „nieludzką ziemię” wraz z Armią 
Polską gen. Władysława Andersa. Autorka wykorzystała materiały zgromadzone w placówkach archiwalnych w Polsce (Archiwum Akt Nowych) oraz za granicą (Archiwum Instytutu Polskiego i Muzeum gen. Sikorskiego w Londynie).

Artykuł Barbary Jundo-KaliszewsKiej (Uniwersytet Łódzki) wprowadza Czytelnika w tematykę bardziej współczesną. Młoda łódzka (ale pochodząca z Wileńszczyzny) badaczka postanowiła dotrzeć i wyjaśnić dwudziestowieczne źródła polsko-litewskich antagonizmów, wywodzących się z okresu II wojny światowej. Bardzo wnikliwie przeanalizowała historyczne doświadczenia obu narodów z okresu okupacji niemieckiej i radzieckiego zniewolenia.

We współczesnej (ale z historią w tle) tematyce polsko-litewskiej pozostaniemy czytając opracowanie AgATY CHUTNIK (Uniwersytet Łódzki), która, wykorzystując liczne wywiady autobiograficzne, naświetliła spojrzenie na Wilno oczami litewskich Polaków. Spostrzeżenia Autorki są szczególnie przydatne, jeśli chcemy zrozumieć dylematy mniejszości polskiej mieszkającej na Litwie, której przedstawiciele często czują rozdarcie pomiędzy własną tożsamością narodową a lojalnością wobec litewskiego państwa.

BogusŁaw Kosel (Uniwersytet w Białymstoku) scharakteryzował materiały archiwalne z zasobów Instytutu Hoovera w Stanford (USA) dotyczące leśników służących w Armii gen. Władysława Andersa (ich kopie przechowywane są w Archiwum Akt Nowych w Warszawie). Mimo wydanych drukiem kilku opracowań dotyczących represji radzieckich wobec tej grupy obywateli polskich (w tym publikacji Autora artykułu), temat ten wciąż nie może zostać uznany za ostatecznie zamknięty. Dlatego wskazówki archiwalne nakreślone przez B. Kosela są niezwykle wartościowe dla tych, którzy chcieliby podjąć się zbadania tej problematyki.

Cykl artykułów w tomie kończy źródło archiwalne w opracowaniu WoJCIECHA MarCiniaKA. Jest to tajna notatka sporządzona przez Wydział Zagraniczny Komitetu Centralnego Polskiej Partii Robotniczej w 1947 r. o sytuacji repatriacyjnej Polaków chcących przyjechać lub powrócić do kraju ze Związku Radzieckiego. Dokument jest świadectwem ogromnej skali trudności (przede wszystkim natury politycznej), jakie powstawały w sprawach przesiedleńczo-repatriacyjnych w stosunkach Warszawy z Moskwą w pierwszym okresie stalinizmu nad Wisłą.

Tom uzupełniają dwa artykuły recenzyjne autorstwa łódzkich historyków: pierwszy - Eweliny Mari Kostrzewskiej i drugi - Przemyslawa WaingertNERA, a także sprawozdanie z konferencji poświęconej prezydentowi Ignacemu Mościckiemu pióra BogumiŁy UmiŃskiej (Muzeum Szlachty Mazowieckiej w Ciechanowie). Mamy nadzieję, że to wprowadzenie okaże się wystarczającą zachętą do lektury obu tomów poświęconych losom Polaków na Wschodzie w XIX-XXI w. 
Jarostaw Kita

Wojciech Marciniak

THE FATE OF POLES IN THE EAST

FROM THE PERIOD OF PARTITIONS, THROUGH THE TRAGIC XX ${ }^{\mathrm{TH}}$ CENTURY TO THE DIFFICULT MODERN TIMES

Siberia, exile, wandering, captivity - there are an experiences accompanying the another genSerations of Poles, who were affected by the oppressive policy of the eastern neighbor of our country - Russia (USSR). Independently from the historical forms of power that had been governed over the Neva or the Kremlin, the Polish fates in the East bring to mind most often these martyrological pages of the history of the native. In fact, the repressions suffered by many Poles from the Russian (and Soviet) state were so severe that it is difficult to make other associations.

The first generation of Polish exiles in Siberia was found themselves there in the XVIII ${ }^{\text {th }}$ century after defeat of the Bar Confederation. The next, significant in terms of numbers the deportations, became a consequence of further lost XIX ${ }^{\text {th }}$ century national uprisings, and in the last decades of the annexation era, they were the result of underground and revolutionary activity undertaken by later generations of Poles.

Twentieth century history is an another chapter - mass repressions against Poles-citizens of the USSR in the 1930s, exiles and deportations of the inhabitants of the Second Polish Republic during World War II, or imprisonment in the camps of the "GULAG archipelago" in the post-war Stalinist period is an era of brutal dissent of the totalitarian regime with Poles. A tsar's deportations, or even a captivity, is something completely different from the Stalinist gulags, prisons and exile. They are connected only by the geographical direction - East.

Słowa kluczowe: losy, Polacy, Wschód, Syberia, XIX-XXI wiek

Keywords: fate, Poles, East, Siberia, $\mathrm{XIX}^{\text {th }}$ century-XX ${ }^{\text {th }}$ century 